\title{
Permanent neonatal diabetes mellitus: clinical presentation and epidemiology in Oman
}

\author{
Bhasker Bappal, Palany Raghupathy, Vasantha de Silva, Saleh Mohamed Al Khusaiby
}

\begin{abstract}
Aim-To estimate the accurate incidence and prevalence of permanent neonatal diabetes mellitus, and to determine the clinical profile of this condition in the Sultanate of Oman.

Methods-All children diagnosed as having permanent neonatal diabetes mellitus between 1991 and 1995 in Oman were included in the study.

Results-The mean incidence was 2.2 per 100000 live births/year and the prevalence among under 5s during 1995 was $2.0 / 100000$. Intrauterine growth retardation was noted in all (mean birthweight $1.86 \mathrm{~kg}$ ), and diabetic ketoacidosis (mean plasma glucose 34.4 (SD 8.7) $\mathrm{mmol} / 1$, mean pH 7.17 (SD 0.09) in 80\%. Hypertriglyceridaemia (mean serum triglyceride 19.06 (6.13) $\mathrm{mmol} /$ ) was constant. No infant had clinical or immunological evidence of congenital viral infections. None had C-peptide excretion or circulating islet cell antibody during diagnosis or follow up. The other important features were parental consanguinity in all, HLA DR3/ DR4 association in $80 \%$, development of autoimmune hypothyroidism in one and observation of autoimmune disorders (insulin dependent diabetes mellitus and Hashimoto's thyroiditis) in family members.
\end{abstract}

Conclusions-These findings strongly suggest an immune mediated aetiology for diabetes mellitus. The reported incidence of permanent insulin dependent neonatal diabetes mellitus in Oman is the highest in the world.

(Arch Dis Child Fetal Neonatal Ed 1999;80:F209-F212)

Paediatric

Endocrinology,

Royal Hospital,

Muscat,

Oman

B Bappal

P Raghupathy

Department of Clinical Pathology

V de Silva

Department of Neonatology

S M Al Khusaiby

Correspondence to: Dr B Bhasker

Paediatric Endocrinology

and Metabolic Unit,

Royal Hospital,

PO Box 1331,

SEEB, Postcode 111

Muscat, Sultanate of Oman.

Accepted 26 November 1998 and yet others may have apparently permanent remission.

There are no accurate epidemiological data on neonatal IDDM in different populations. Transient diabetes mellitus is not reported uniformly. The reported incidence of PNIDDM is around 1 in 400000 live births, ${ }^{6}$ or 1 in 500 000 neonates, ${ }^{1}$ as noted in various regions. Two cases of PNIDDM diagnosed in our hospital within a year prompted us to undertake this study. This study aimed to estimate the accurate incidence and prevalence rates of PNIDDM and to determine the clinical profile of this condition in the Sultanate of Oman.

\section{Methods}

All children with PNIDDM studied were native Omanis. They were treated and regularly followed up in the paediatric endocrinology clinic at the Royal Hospital, Muscat, which is the nation's tertiary hospital. All complex and rare diseases are referred, as a rule, to this federal centre and new cases reported.

The clinical profiles of children with PNIDDM were analysed. The criteria for diagnosis of PNIDDM were defined earlier. Children under the age of 5 years with IDDM diagnosed during 1991-95 were also evaluated to calculate the prevalence among under $5 \mathrm{~s}$. IDDM was diagnosed according to WHO criteria. ${ }^{7}$ The date of the first insulin injection was taken as the date of diagnosis. Children with secondary diabetes were excluded. Incidence and prevalence rates were calculated by using the final results of the general census of population published yearly by the Ministry of Health, Sultanate of $\mathrm{Oman}^{8} ; 95 \%$ confidence intervals were calculated as described by Armitage and Berry ${ }^{9}$ and Pearson correlation coefficients were calculated for clinical variables.

The results of the following investigations carried out during the initial presentation and admission were analysed: venous blood gas analysis, serum concentrations of glucose, cholesterol, triglycerides, electrolytes, urea, and creatinine were carried out using standard laboratory methods. Blood was screened for the presence of $\operatorname{IgG}$ and $\operatorname{IgM}$ antibodies against toxoplasma, cytomegalovirus, and other viruses-rubella, Coxsackie, and herpes. Indirect immunofluorescence technique (Serono laboratories, Cambridge, UK) on human pancreatic sections was done for detecting the presence of islet cell antibody. Plasma C-peptide concentration was estimated by radioimmunoassay. Glycated haemoglobin was determined using Abbott IMX glycated haemoglobin assay test kits. HLA typing of the 
Table 1 Baseline characteristics of the children with PNIDDM

\begin{tabular}{|c|c|c|c|c|c|c|c|c|}
\hline \multirow[b]{2}{*}{$\begin{array}{l}\text { Case } \\
\text { No }\end{array}$} & \multirow[b]{2}{*}{$\begin{array}{l}\text { Gestational } \\
\text { age (weeks) }\end{array}$} & \multicolumn{3}{|l|}{ At birth } & \multicolumn{3}{|c|}{ At presentation } & \multirow[b]{2}{*}{$\begin{array}{l}\text { Weight } \\
\text { gain } \\
\text { (g/day }\end{array}$} \\
\hline & & $\begin{array}{l}\text { Weight } \\
(\mathrm{kg})\end{array}$ & $\begin{array}{l}\text { Length } \\
(\mathrm{cm})\end{array}$ & $\begin{array}{l}\text { Head } \\
\text { circumference } \\
(\mathrm{cm})\end{array}$ & $\begin{array}{l}\text { Age } \\
\text { (days) }\end{array}$ & $\begin{array}{l}\text { Duration of } \\
\text { symptoms } \\
\text { (days) }\end{array}$ & $\begin{array}{l}\text { Weight } \\
(\mathrm{kg})\end{array}$ & \\
\hline 1 & 39 & 1.85 & 47 & 32 & 20 & 2 & 1.92 & 4 \\
\hline 2 & 38 & 1.52 & 40 & 32 & 18 & 8 & 1.63 & 6 \\
\hline 3 & 37 & 2.1 & 47 & 32 & 14 & 4 & 2.30 & -14 \\
\hline 4 & 38 & 1.5 & 41 & 37 & 19 & 5 & 1.65 & 8 \\
\hline 5 & 38 & 2.35 & 48 & 35 & 6 & 3 & 2.20 & -25 \\
\hline
\end{tabular}

patients was performed at the National Tissue Typing Reference Laboratory, Sultan Qaboos University, Muscat, Oman.

All the children with PNIDDM were treated with a standard insulin schedule, combining intermediate and short acting human insulin preparations, once or twice a day, as required. The children were reviewed monthly during the first year and every two months thereafter. Growth and the degree of clinical and biochemical control were periodically assessed in all children prospectively. Serial C-peptide estimations were carried out in the first year after diagnosis. Thyroid function tests and skeletal age assessment, if considered necessary, were carried out annually.

\section{Results}

Five cases of PNIDDM were diagnosed during the five years under study, two cases in 1991 and one each during the calendar years 1993 95. The incidence of PNIDDM/100 000 live births in Oman was 4.4 in 1991, 0 in 1992, 2.1 in 1993, 2.2 in 1994 and 2.3 in 1995. The numbers of live births in Oman during these years were as follows: 45080 in $1991 ; 47175$ in 1992; 46779 in 1993; 45753 in 1994 and 44148 in $1995 .{ }^{8}$ The mean incidence during the study period was $2.2 / 100000$ live births/ year. At the end of December 1995 the prevalence of PNIDDM in children under 5 years of age $(n=252660)^{8}$ was 2.0 per $100000 ; 95 \%$ confidence interval 0.24 to 3.71. Children with PNIDDM constituted $8.8 \%$ of all cases $(n=57)$ of IDDM in this age group.

The current incidence of consanguineous marriages in the Sultanate of Oman is as follows: first cousins $24 \%$, second cousins $11 \%$, and a further $20.4 \%$ within the members of the same tribe, making a total of $55.5 \% .{ }^{10}$ Consanguinity was noted in the parents of all patients with PNIDDM. Among the five children with PNIDDM from four families, three were the offspring of first cousin marriages and two were siblings born to second cousins. The prevalence of IDDM and NIDDM among their siblings, parents, and close relatives was significantly high. The father and the paternal aunt of the two siblings (cases 3 and 5) had IDDM, while their grandfather and granduncle had NIDDM. The mother of another child had gestational diabetes. Hashimoto's thyroiditis developed in one mother and vitiligo in another. The age of onset of the first symptom ranged from 6 to 20 days and the mean age of onset was 15.4 days (table 1 ). The duration of symptoms reported by parents before diagnosis ranged from 2 to 8 days and the mean duration was 4.4 days. The presenting symptoms were: fever $4 / 5$, lethargy and poor feeding $4 / 5$, polyuria $4 / 5$, diarrhoea and dehydration 5/5 and tachypnoea 4/5.

The birthweights ranged from $1.5 \mathrm{~kg}$ to 2.3 $\mathrm{kg}$ with a mean weight of $1.86 \mathrm{~kg}$. All of the infants had IUGR. The mean weight at diagnosis was $1.94 \mathrm{~kg}$ (table 1 ).

Laboratory results at presentation are shown in table 2. The mean (SD) blood glucose concentration before starting treatment was 34.4 (8.7) $\mathrm{mmol} / \mathrm{l}$. Blood glucose concentrations was not related to the age of onset nor to the duration of symptoms. Mean (SD) blood $\mathrm{pH}$ was 7.17 (0.09) and $80 \%$ had $\mathrm{pH}<7.2$. Blood $\mathrm{pH}$ was correlated significantly with blood glucose $(r=-0.96, p<0.01)$. Mild to moderate ketonuria was found in four out of five patients. Serum triglyceride concentrations were significantly high (mean (SD) 19.06 (6.13) mmol/l) in all infants.

Electrolyte abnormalities included hyponatraemia (serum sodium $<130 \mathrm{mmol} / \mathrm{l}$ ) in $60 \%$, hyperkalaemia (serum potassium $>5.5 \mathrm{mmol} / \mathrm{l}$ ) in $20 \%$. Serum sodium concentration did not correlate significantly with blood glucose concentration $(\mathrm{r}=-0.55, \mathrm{p}=0.34)$ nor did serum potassium concentration with $\mathrm{pH}(\mathrm{r}=0.71$, $p=0.18$ ). Pre-renal uraemia (blood urea $>7.5$ $\mathrm{mmol} / 1$ ) was seen in $80 \%$ of patients and was not correlated with serum creatinine $(\mathrm{r}=0.04, \mathrm{p}=0.95)$. Viral and toxoplasma antibodies against rubella, cytomegalovirus, and Coxsackie virus (IgM and IgG classes) were not detected in any of our patients at presentation, and there was no history of a clinically significant viral illness in the mothers during pregnancy. Islet cell antibody was not detected in any of the five infants at presentation.

During the first year of life, symptomatic hypoglycaemia occurred in three infants, accounting for five admissions; three episodes of ketoacidosis occurred in three patients. The mean insulin requirement in the first year after diagnosis was $0.67(0.1)$ unit $/ \mathrm{kg} /$ day. None of the patients had evidence of complete or partial remission (honeymoon phase). Plasma C-peptide concentrations at the time of presentation were $<0.199 \mathrm{pmol} / 1$ during

Table 2 Laboratory data of children with PNIDDM at initial presentation

\begin{tabular}{|c|c|c|c|c|c|c|c|c|c|}
\hline Case No & $\begin{array}{l}\text { Blood } \\
\text { glucose } \\
\text { (mmol/l) }\end{array}$ & Venous $p H$ & $\begin{array}{l}\text { Urinary } \\
\text { ketones }\end{array}$ & $\begin{array}{l}\text { Serum } \\
\text { triglycerides } \\
\text { (mmolll) }\end{array}$ & $\begin{array}{l}\text { Serum } \\
\text { cholesterol } \\
(\mathrm{mmol} / \mathrm{l})\end{array}$ & $\begin{array}{l}\text { Serum } \\
\mathrm{Na}^{+} \\
(\mathrm{mmol} / \mathrm{l})\end{array}$ & $\begin{array}{l}\text { Serum } K^{+} \\
(\text {mmolll })\end{array}$ & $\begin{array}{l}\text { Blood urea } \\
\text { (mmol/l) }\end{array}$ & $\begin{array}{l}\text { Serum } \\
\text { creatinine } \\
(\mu \mathrm{mol} / \mathrm{l})\end{array}$ \\
\hline 1 & 43 & 7.082 & $2+$ & 23.9 & 1.7 & 128 & 5 & 10.2 & 63 \\
\hline 2 & 34 & 7.22 & $1+$ & 20 & 4 & 123 & 4.8 & 9.6 & 60 \\
\hline 3 & 38 & 7.12 & $2+$ & 22 & 2.5 & 129 & 5.8 & 9.2 & 78 \\
\hline 4 & 37 & 7.12 & $2+$ & 21 & 4.2 & 130 & 4.8 & 8.9 & 62 \\
\hline 5 & 20 & 7.32 & Nil & 8.4 & 3 & 134 & 4.2 & 5.1 & 64 \\
\hline Mean (SD) & $34.4(8.7)$ & $7.12(0.09)$ & & $19.41(4.87)$ & $3.08(1.04)$ & & & & \\
\hline
\end{tabular}


hyperglycaemia, in all the patients studied. Serial C-peptide estimations did not reveal any evidence of endogenous insulin secretion. The common HLA loci associated with IDDM (DR3 and/or DR4) were found in $80 \%$ of the patients studied $(n=5)$. Autoimmune hypothyroidism was diagnosed in one infant by the presence of thyroid antibodies and biochemical evidence of hypothyroidism.

One child died at the age of 2.5 years after aggressive hepatitis and liver failure following transfusion.

\section{Discussion}

IDDM in neonates is very rare. The incidence of IDDM increases with age and the highest incidence is seen around adolescence. The epidemiological aspects of PNIDDM have not been studied. The mean yearly incidence of PNIDDM per 100000 live births in Oman from 1991 to 1995 was 2.2/year. During 1995, the prevalence of PNIDDM in the age group 0 to 5 years was $2.0 / 100000$. The incidence of PNIDDM during the five years of the study is the highest reported in the world. This could be related to the high degree of consanguinity in the Omani population, as noted earlier. Interestingly, there was a significant history of consanguinity in all the four families studied.

As noted in earlier reports, ${ }^{11}{ }^{12}$ all our patients had IUGR with a mean birthweight of $1.9 \mathrm{~kg}$. Insulin secreted by the fetal pancreas has a significant role in growth and metabolism of the fetus during the last half of gestation. ${ }^{13}{ }^{14}$ Knip et $a l^{15}$ suggested that intrauterine insulin deficiency could be the cause of IUGR in these patients.

Diabetes diagnosed in older children seems to present much less acutely than in neonates. Ketoacidosis was the initial presentation in $80 \%$ of infants with PNIDDM. This figure is much higher than that of older children. In a series reported by Salman et al $70.8 \%$ of children below 5 years and $65.8 \%$ of children above 5 years presented with ketoacidosis. ${ }^{16}$ The duration of symptoms before diagnosis in our study ranged from 2 to 8 days, with a median of 4.4 days. The shorter duration of symptoms in neonates compared with older children might reflect either a faster deterioration of their $\beta$ cell function, higher requirement of insulin $/ \mathrm{kg}$, and/or their increased susceptibility to dehydration compared to older infants and children. ${ }^{17}$

Complete remission occurs in 3\% of children with IDDM and partial remission (insulin requirement less than $0.5 \mathrm{unit} / \mathrm{kg} /$ day) occurs in around two thirds of children with IDDM. ${ }^{18}$ None of our patients with PNIDDM experienced partial or complete remission during the first year of life. This may be explained by the severity of $\beta$ cell destruction. None of them had detectable circulating C-peptide concentration at presentation or during the first year after diagnosis, supporting the view of total destruction of their $\beta$ cell mass. Two children developed autoimmune thyroiditis at the age of 1.5 and 3 years with raised antimicrosomal thyroid antibodies and high thyroid stimulating hormone activities.
The cause of $\beta$ cell destruction in PNIDDM is not yet known. In general, in IDDM the process of $\beta$ cell destruction in a genetically predisposed host by environmental agents (virus, toxins) is relatively slow. It may take many months or years for the overt diabetes to present itself. ${ }^{19-27}$ For diabetes to occur in the neonatal period the pathological process causing islet cell damage or destruction should clearly start in utero. In general, more than $80 \%$ of islet cells do not show $\beta$ cells when IDDM unfolds clinically. ${ }^{21}{ }^{22}$ At present, there are no studies to indicate whether the process of islet cell destruction in PNIDDM starts in utero. In the case reported by Dodge $e t a l^{11}$ no islet cells were seen in the neonate who died of diabetes at the age of 3 days. In all our cases the C-peptide secretion was absent at presentation (as early as the 8th day of life), concomitant with evidence of intrauterine growth retardation due to lack of the anabolic effect of insulin. These findings support the view that the $\beta$ cell destruction starts in utero.

There was no historical, clinical, or immunological evidence of congenital infection at birth in any of the cases studied. However, we found a significant number of autoimmune mediated diseases in the affected neonates and their families including a high incidence of IDDM in siblings and their parents. PNIDDM has been reported in a mother and her son, ${ }^{28}$ and among siblings. ${ }^{29}$ We also found Hashimoto's thyroiditis in one mother and autoimmune hypothyroidism in one child. IDDM and PNIDDM have occurred in the members of the same family. ${ }^{28} 30$

The absence of islet cell antibodies in all our patients at presentation might point to a different mode of immune reaction in this age group. Non-islet cell antibody against interstitial tissue among the acinar cells was shown in two HLA Dw 3/4 positive siblings. ${ }^{29}$

The common HLA loci associated with IDDM (DR3 and/or DR4) were found in 80\% of the patients studied. This finding, in addition to the high degree of parental consanguinity $(100 \%)$, high prevalence of IDDM, and other autoimmune disorders in the patients and their parents and siblings, strongly supports an immune aggression aetiology for their diabetes.

We thank Professor A White, formerly Head of the National Tissue Typing Reference Laboratory, Sultan Qaboos University, Muscat, Sultanate of Oman, for carrying out HLA testing and Dr B Antonisamy, Department of Biostatistics, Christian Medical College Hospital, Vellore, India, for his help with statistical analysis. Case 4 was managed initially by Dr Ashraf Soliman.

1 von Muhlendahl KE, Herkenhoff $\mathrm{H}$. Long-term course of neonatal diabetes. N Engl 7 Med 1995;333:704-8.

2 Holland CL, Holland EA. Diabetes mellitus in infancy. $W$ Virginia Med $\mathcal{F}$ 1936;32:407-9.

3 Guest GM. Diabetes mellitus in early infancy, treated without dietary restrictions. Acta Paediatr 1949;38:196-208

4 Wylie MES. A case of congenital diabetes. Arch Dis Child 1953;28:297-301

5 Assevero VL, Moss JM. Diabetes in infancy. $f$ Pediatr 1958;53:227-9

6 Shield JPH, Gardner RJ, Wadsworth EJK, et al. Aetiopathology and genetic basis of neonatal diabetes. Arch Dis Child 1997;76:F39-42.

7 World Health Organization Expert Committee on Diabetes Mellitus. Second Report. Technical Report Series 646. Geneva: WHO, 1980.

8 Annual Statistical Reports. Series issued by Ministry of Health, Sultanate of Oman, 1992-1996. 
9 Armitage P, Berry G. Statistical methods in medical research. 2nd edn. Oxford: Blackwell Scientific, 1987:117-20.

10 Rajab A, Patton MA. Consanguinity in the Sultanate of Oman. Difficulties in accurate measurement of inbreeding. (in press).

11 Dodge JA, Laurence KM. Congenital absence of islets of Langerhans. Arch Dis Child 1977;52:411-19.

12 Greenwood RD, Traisman HS. Permanent diabetes mellitus in a neonate. $\mathcal{F}$ Pediatr $971 ; 79: 296-8$

13 Sperling MA. Carbohydrate metabolism: Insulin and glucagon. In: Tulchinsky D, Little A, eds. Maternal foetal endocrinology. Philadelphia: WB Saunders Company,
1994:379-400.

14 Dorchy $\mathrm{H}$, Oome $\mathrm{H}$, Loeb $\mathrm{H}$. Insulin secretion in a case of permanent neonatal diabetes mellitus. In: Laron A, ed. Modern problems of paediatrics. Basel: S Karger, 1975:6772 .

15 Knip M, Koivisto M, Kaar M-L, et al. Pancreatic islet cell function and metabolic control in an infant with function and metabolic control in an infant with permanent neon

16 Salman H, Abanamy A, Ghassan B, Khalil M. Insulin dependent diabetes mellitus in children: Familial and clinical pattern in Riyadh. Ann Saudi Med 1997;11 $302-5$

17 Tarn AC, Smith CP, Spencer KM, et al. Type 1 (insulin dependent) diabetes: a disease of slow clinical onset? $B M \mp$ 1987;294:342-5.

18 Drash AL. Management of the child with diabetes mellitus: Clinical course, therapeutic strategies, and monitoring techniques. In: Lifshitz F, ed. Pediatric endocrinology. New York: Marcel Dekker, 1990:681-700.

19 Campbell IL, Harrison LC. Molecular pathology of type 1 diabetes. Mol Biol Med 1990;7:299-309.
20 Riley WJ, Maclaren NK, Krischer J, et al. A prospective study of the development of diabetes in relatives of patients with insulin-dependent diabetes. 1990;323:1167-72

21 Srikanta S, Ganda OP, Rabizadeh DMD, Soeldner JS. First-degree relatives of patients with type 1 diabetes mellitus: islet-cell antibodies and abnormal insulin secretion. N Engl F Med 1985;313:461-4.

22 Bruining GJ, Molenaar JL, Grobbee DE. Ten-year follow-up study of islet-cell antibodies and childhood diabetes mellitus. Lancet 1989;i:1100-13

23 Cahill JF Jr, McDevitt, HO. Insulin dependent diabetes mellitus: The initial lesion. N Engl f Med 1981;304:145464.

24 Eisenbarth, GS. Type 1 diabetes mellitus. A chronic autoimmune disease. N Engl f Med 1986;314:1360-8.

25 Gamble DR, Tyler KW, Cumming H. Coxsackie virus in diabetes mellitus. BMF 1984;4:262.

26 Pak CY, McArthur GR, Eun HM, Yoon JW. Association of cytomegalovirus infection with autoimmune type 1 cytomegalovirus infection
diabetes. Lancet 1988;ii: $1-4$.

27 Karam JH, Lewitt PA, Young CW. Insulinopenic diabetes after rodenticide (Vacor) ingestion. $N$ Engl $f \mathrm{Med}$

28 John AW, Richard MC, Patrick WZ, et al. Permanent neonatal diabetes in an infant of an insulin dependent mother. $f$ Pediatr 1982;100:926-9.

29 Ivarsson S-A, Marner B, Lernmark A, Nilsson KO. Nonislet pancreatic autoantibodies in sibship with permanent neonatal insulin-dependent diabetes mellitus. Diabetes 1988;37:347-50.

30 Hattevig G, Kjellman B, Fallstrom SP. Congenital permanent diabetes mellitus and celiac disease. $f$ Pediatr 1982;101:955-7. 